\title{
Ras Activation by Insulin and Epidermal Growth Factor through Enhanced Exchange of Guanine Nucleotides on p21 ras
}

\author{
RENÉ H. MEDEMA, ${ }^{1}$ ALIDA M. M. DE VRIES-SMITS, ${ }^{1}$ GERARD C. M. VAN DER ZON, ${ }^{2}$ \\ J. ANTONIE MAASSEN, ${ }^{2}$ AND JOHANNES L. BOS ${ }^{1 *}$ \\ Laboratory for Physiological Chemistry, University of Utrecht, Vondellaan 24A, 3521 GG Utrecht, ${ }^{1}$ \\ and Laboratory of Protein Synthesis and Hormone Regulation, Sylvius Laboratory, \\ 2333 AL Leiden, ${ }^{2}$ The Netherlands
}

Received 21 August 1992/Returned for modification 21 September 1992/Accepted 23 October 1992

\begin{abstract}
A number of growth factors, including insulin and epidermal growth factor (EGF), induce accumulation of the GTP-bound form of $\mathbf{p 2}^{\text {ras }}$. This accumulation could be caused either by an increase in guanine nucleotide exchange on $\mathbf{p}^{\text {ras }}$ or by a decrease in the GTPase activity of p21 ${ }^{\text {ras }}$. To investigate whether insulin and EGF affect nucleotide exchange on p21 ras, we measured binding of $\left[\alpha^{-32} P\right] G T P$ to $21^{\text {ras }}$ in cells permeabilized with streptolysin 0 . For this purpose, we used a cell line which expressed elevated levels of p21 H-ras and which was highly responsive to insulin and EGF. Stimulation with insulin or EGF resulted in an increase in the rate of nucleotide binding to $\mathbf{p 2 1}^{\text {ras }}$. To determine whether this increased binding rate is due to the activation of a guanine nucleotide exchange factor, we made use of the inhibitory properties of a dominant negative mutant of p21 ${ }^{\text {ras }}$, p21 $^{\text {ras }}\left(\right.$ Asn-17). Activation of p21 $^{\text {ras }}$ by insulin and EGF in intact cells was abolished in cells infected with a recombinant vaccinia virus expressing $\mathbf{p}^{21}{ }^{\text {ras }}$ (Asn-17). In addition, the enhanced nucleotide binding to $\mathrm{p21}^{\text {ras }}$ in response to insulin and EGF in permeabilized cells was blocked upon expression of p21 ${ }^{\text {ras }}\left(\mathbf{A s n}^{-17}\right)$. From these data, we conclude that the activation of a guanine nucleotide exchange factor is involved in insulinand EGF-induced activation of $\mathbf{p 2 1}{ }^{\text {ras }}$.
\end{abstract}

The products of the ras proto-oncogenes are small proteins of $21 \mathrm{kDa}$ that bind guanine nucleotides and are located on the inner side of the plasma membrane (2). These proteins play an important role in signal transduction from a variety of receptors that belong to the tyrosine kinase family (25). The ras proteins are activated through conversion of the inactive GDP-bound form into the active GTP-bound form. When bound to GTP, ras proteins can induce a number of cellular responses, such as activation of serine-threonine kinases (29), expression of early response genes (44), and mitogenicity $(21,43)$. Oncogenic mutations in the ras protooncogene that enable p21 ras to transform cells in culture lead to accumulation of the GTP-bound form, either through enhanced nucleotide exchange or through decreased intrinsic GTPase activity (34).

Evidence that activation of $\mathrm{p} 21^{\text {ras }}$ plays a crucial role in the signal transduction of external signals comes from experiments in which the function of normal p21 ras has been inhibited. Microinjection of neutralizing antibodies to $\mathrm{p} 21^{\text {ras }}$ results in the inhibition of growth factor-induced mitogenicity (37) and gene expression (44). Also, the expression of dominant negative mutants of $21^{\text {ras }}$ blocks the induction of extracellular signal-regulated kinases $(16,47,51)$, gene expression $(14,35)$, and differentiation $(45)$ by several of these growth factors. A number of external signals that control the activity of $\mathrm{p} 21^{\text {ras }}$ have been characterized. First, in T cells, stimulation of the $\mathrm{T}$-cell receptor leads to a rapid activation of p21 ras (18). Secondly, in fibroblasts, stimulation with a variety of growth factors results in ras activation; of these, insulin and epidermal growth factor (EGF) seem to have the most profound effect on the activation state of $\mathrm{p}^{2} 1^{\text {ras }}(12,23$, $38,40,41)$.

The GTP/GDP cycle of normal $\mathrm{p} 21^{\text {ras }}$ is controlled by two

\footnotetext{
* Corresponding author.
}

classes of regulatory proteins $(7,8)$. The activation state of $\mathrm{p} 21^{\text {ras }}$ is negatively regulated by GTPase-activating proteins (GAPs), which accelerate the hydrolysis of the bound GTP to GDP. Two GAPs have been identified in mammalian cells: p120GAP (48) and the product of the neurofibromatosis type 1 gene, neurofibromin $(1,33,52)$. Deletion of the neurofibromin gene leads to increased levels of ras-GTP (3), and overexpression of p120GAP decreases the amount of rasGTP in NIH 3T3 cells (23), indicating that these proteins play an important role in regulating the activation state of p21 ras. Apart from regulating the GTP/GDP balance of p $21^{\text {ras }}$, both proteins have previously been proposed to be mediators of signal transduction from ras-GTP (4). In Saccharomyces cerevisiae, two proteins have been previously shown to negatively regulate the activity of the yeast RAS proteins IRA1 and IRA2 (46). Deletion of IRA1 or IRA2 results in a phenotype similar to that of the oncogenic RAS2(Val-19) mutant (46). More recently, a putative GAP with similarity to mammalian p120GAP was cloned from Drosophila melanogaster (22). Inactivation of this Gap1 locus mimics constitutive activation of the sevenless receptor, which has previously been suggested to activate the Drosophila Ras1 protein (22). Positive regulation, i.e., activation of $\mathrm{p} 21^{\text {ras }}$ by the replacement of GDP for GTP, requires the action of an exchange factor that facilitates dissociation of GDP. This will result in the subsequent binding of GTP, since levels of GTP predominate over those of GDP in the cytoplasm of intact cells. In cell and tissue extracts, both cytoplasmic and membrane-bound exchange activities have previously been identified, and these factors have been partially purified $(19,49,50)$. Recently, the cloning of mammalian exchange factors for $\mathrm{p} 21^{\text {ras }}$ from a mouse brain cDNA library (32) and from a rat brain cDNA library (42) has been reported. In lower eukaryotes, exchange proteins have been characterized in more detail. In $S$. cerevisiae, the nucleotide exchange on RAS is controlled 
by CDC25 (9) as well as by a C-terminal fragment of SDC25 (15). In D. melanogaster, the product of son of sevenless has been indicated as the exchange factor for $\mathrm{p} 21^{\text {ras }}$ on the basis of its homology to CDC25 (6). However, it is still unclear whether the activity of these exchange factors is regulated by external signals, although indirect evidence suggests that EGF might enhance the affinity of $\mathrm{p} 21^{\text {ras }}$ for guanine nucleotides (27). Therefore, we investigated whether the exchange activity of guanine nucleotides on $\mathrm{p} 21^{\text {ras }}$ is altered in response to growth factors that activate $\mathrm{p} 21^{\text {ras }}$.

The rate of nucleotide exchange on $21^{\text {ras }}$ in permeabilized cells expressing elevated levels of p21H-ras was measured. We observed an increase in the rate at which $\mathrm{p} 21^{\text {ras }}$ binds $\left[\alpha-{ }^{32} \mathrm{P}\right] \mathrm{GTP}$ in these permeabilized cells in response to insulin and EGF. Furthermore, in this article we show that this enhanced binding rate is inhibited by a dominant negative mutant of $\mathrm{p}^{2} 1^{\text {ras }}, \mathrm{p} 21^{\text {ras }}$ (Asn-17). In addition, expression of ras(Asn-17) inhibited the activation of $\mathrm{p} 21^{\text {ras }}$ in intact cells by insulin and EGF. From these data, we conclude that insulin- and EGF-induced activation of p21 ras is, at least in part, mediated by the increased activity of an exchange factor for $\mathrm{p} 21^{\text {ras }}$.

\section{MATERIALS AND METHODS}

Cell culture. The $\mathrm{H} 13$ cell line is a Rat-1-derived cell line overexpressing H-ras (approximately 100 -fold), and it was a kind gift from J. Downward (17). H13 cells were cultured in Dulbecco's modified eagle medium (DMEM) (GIBCO) supplemented with $10 \%$ fetal calf serum (FCS) (GIBCO) $-0.05 \%$ glutamine. The H13IR2000 cell line was constructed by transfecting $\mathrm{H} 13$ fibroblasts with an expression vector containing the human insulin receptor cDNA and a dihydrofolate reductase selection marker. After stepwise amplification with methotrexate up to $2,000 \mathrm{nM}$, a clonal line, H13IR2000, was obtained. This cell line contains about $8 \times 10^{5}$ insulin receptors per cell (38). H13IR2000 cells were routinely grown in DMEM supplemented with $10 \%$ dialyzed FCS$0.05 \%$ glutamine plus $2 \mu \mathrm{M}$ methotrexate. Prior to in vivo labeling and permeabilization experiments, H13IR2000 cells were transferred to DMEM-10\% FCS without methotrexate for at least $18 \mathrm{~h}$. A14 cells are NIH 3T3-derived cells expressing $7 \times 10^{5}$ human insulin receptors per cell (12). RR3 cells are Rat-1-derived cells transformed with oncogenic p21 ras, ras (Val-12), and they have been described previously (13). RR3, A14, and Rat-1 cells were grown in DMEM-10\% FCS supplemented with $0.05 \%$ glutamine.

In vivo labeling of $\mathbf{p 2 1}^{\text {ras }}$. Subconfluent cultures of A14, Rat-1, H13, and H13IR2000 were grown in DMEM-0.5\% FCS for $18 \mathrm{~h}$ prior to in vivo labeling. Cells were washed three times with phosphate-free DMEM (Sigma) and labeled with $0.1 \mathrm{Ci}$ of ${ }^{32} \mathrm{P}_{\mathrm{i}}$ per $\mathrm{ml}(3,000 \mathrm{Ci} / \mathrm{mmol}$; Amersham) for 3 to $5 \mathrm{~h}$. After being stimulated with the appropriate growth factor, cells were lysed as described previously (12). Fully processed, membrane-bound p21 ras was separated from nonprocessed p $21^{r a s}$ by a Triton X-114 phase-split as described previously $(12,24)$. From the detergent phase, processed p $21^{\text {ras }}$ was immunoprecipitated with the monoclonal antibody Y13-259. Alternatively, immunoprecipitation was carried out with another ras-specific antibody (Y13-238) or with a nonrelated antibody directed against simian virus 40 large $\mathrm{T}$ (kT3) as a control. After extensive washing of the immunoprecipitates, bound guanine nucleotides were eluted as described previously (12). Nucleotides eluted from p21 $1^{\text {ras }}$ were separated by ascending thin-layer chromatography (TLC) as described previously (12), and spots corresponding to GTP and GDP were cut out. The amount of ${ }^{32} \mathrm{P}$ present in each spot was determined by scintillation counting.

Cell permeabilization. Subconfluent cultures of $\mathrm{H} 13$, H13IR2000, and RR3 (5-cm-diameter dishes) were serum starved for $18 \mathrm{~h}$ prior to permeabilization. Cells were stimulated with the appropriate growth factor, the medium was aspirated, and then the dishes were washed once with warm phosphate-buffered saline (PBS) $\left(37^{\circ} \mathrm{C}\right)$. To each dish, $0.8 \mathrm{ml}$ of freshly prepared permeabilization buffer $(150 \mathrm{mM} \mathrm{KCl}$, $37.5 \mathrm{mM} \mathrm{NaCl}, 6.25 \mathrm{mM} \mathrm{MgCl}, 0.8 \mathrm{mM} \mathrm{CaCl}, 1 \mathrm{mM}$ EGTA, $1.25 \mathrm{mM}$ ATP, $12.5 \mathrm{mM}$ PIPES [piperazine- $N, N^{\prime}$ bis(2 ethanesulfonic acid)] [pH 7.4]) was added and diluted with $0.2 \mathrm{ml}$ of streptolysin $\mathrm{O}$ in water $(2 \mathrm{U} / \mathrm{ml}$; Wellcome Diagnostics). To each dish, $1 \mu$ l of $\left[\alpha^{-32} \mathrm{P}\right] \mathrm{GTP}(3,000 \mathrm{Ci} /$ mmol; Amersham) was added immediately (time point zero), and at discrete time points, cells were lysed and p $21^{\text {ras }}$ was immunoprecipitated with the antibody Y13-259 as described in "In vivo labeling of p21 ras." In experiments in which binding of $\left[\alpha-{ }^{32} \mathrm{P}\right]$ GTP to $\mathrm{p} 21^{\text {ras }}$ was compared with binding to total cellular proteins, $\left[\alpha-{ }^{32} \mathrm{P}\right] \mathrm{GTP}$ was diluted with $10 \mu \mathrm{M}$ unlabeled GTP to minimize variations in the specific activity. A chase of the labeled nucleotides bound to p21 ras after a 10 -min exposure to $3 \mathrm{nM}\left[\alpha-{ }^{32} \mathrm{P}\right] \mathrm{GTP}$ was performed by adding $1 \mathrm{mM}$ unlabeled GTP to the permeabilized cells. At discrete time points, cells were lysed and the amount of labeled nucleotide remaining on $\mathrm{p} 21^{\text {ras }}$ was determined.

Filter binding of total lysates on nitrocellulose. Permeabilized cells exposed to $\left[\alpha-{ }^{32} \mathrm{P}\right] \mathrm{GTP}$ in the presence of $10 \mu \mathrm{M}$ unlabeled GTP were washed once with cold PBS. Cells were lysed in $500 \mu$ l of lysis buffer as described in "In vivo labeling of p21 ras." After phase separation, $100 \mu l$ of the aqueous phase was filtered through a nitrocellulose filter (Millipore, type HA, $0.45-\mu \mathrm{m}$ pore size). Filters were washed four times with $10 \mathrm{ml}$ of ice-cold wash buffer $(20 \mathrm{mM}$ Tris- $\mathrm{Cl}$ [pH 7.5], $20 \mathrm{mM} \mathrm{NaCl}, 5 \mathrm{mM}$ 2-mercaptoethanol, 3 $\mathrm{mM} \mathrm{MgCl}$ ) and counted in $4 \mathrm{ml}$ of scintillation liquid.

Construction and expression of $\mathbf{p}^{\text {ras }}($ Asn-17) recombinant vaccinia virus. The dominant negative mutant of $\mathrm{p} 21^{\text {ras }}$, ras(Asn-17), was introduced into a viral growth factor minus strain of vaccinia virus to avoid autocrine stimulation of the infected cells by the viral growth factor (10). This vaccinia virus strain was a kind gift from $B$. Moss, and the ras(Asn17) mutant gene was inserted through homologous recombination as described previously (16). Six additional histidine codons were inserted after the AUG start codon of the $\mathrm{H}$-ras(Asn-17) gene (16) to allow binding to $\mathrm{Ni}^{2+}$-nitrilotriacetic acid $\left(\mathrm{Ni}^{2+}-\mathrm{NTA}\right)$ agarose (Qiagen) (26). Wild-type and recombinant viruses were grown in HeLa cells (titer, $10^{9}$ virus particles per ml). H13IR2000 cells were infected with 10 PFU of recombinant or wild-type virus per cell in serumfree medium. After $60 \mathrm{~min}$, the medium was replaced with DMEM-0.5\% FCS and $10 \mathrm{mM}$ hydroxyurea to block DNA synthesis and late viral expression. Sixteen to $18 \mathrm{~h}$ after infection, cells were used for in vivo labeling or permeabilization experiments. Analysis of the guanine nucleotides bound to p21 ras was performed as described under "In vivo labeling of p21 ras," with one minor modification: all lysates were precleared with $\mathrm{Ni}^{2+}$-NTA agarose $(15-\mu \mathrm{l}$ bead volume, $15 \mathrm{~min}$ at $4^{\circ} \mathrm{C}$ ), instead of being precleared with $50 \mu \mathrm{l}$ of protein A agarose as usual. Expression of ras(Asn-17) was checked by binding of ras(Asn-17) recombinant protein to $\mathrm{Ni}^{2+}$-NTA agarose through 6 histidine residues at the $\mathrm{N}$ terminus. After binding of recombinant ras(Asn-17), wildtype ras was immunoprecipitated with Y13-259. Samples were separated on a $15 \%$ polyacrylamide gel, blotted onto nitrocellulose, and incubated with Y13-259. Immune com- 
plexes were detected first by horseradish peroxidase second antibodies and then by enhanced chemiluminescence.

\section{RESULTS}

Insulin- and EGF-induced activation of $21^{\text {ras }}$. We have constructed a cell line (H13IR2000) which expresses elevated levels of both p21 H-ras and the human insulin receptor. To test whether the activation state of $\mathrm{p} 21^{\text {ras }}$ is regulated by insulin in H13IR2000 cells, these cells were labeled with ${ }^{32} \mathrm{P}_{\mathrm{i}}$, and then the guanine nucleotide ratio bound to p21 ras was analyzed. Stimulation of H13IR2000 cells with insulin for 5 min resulted in an increase in the level of GTP-bound p $21^{\text {ras }}$, from $\sim 7$ to $\sim 40 \%$ of total bound guanine nucleotides (Fig. 1A). This increase is similar to that observed previously with NIH 3T3 cells overexpressing the human insulin receptor (A14 cells) (12). Treatment of H13IR2000 cells with EGF for 5 min resulted in an activation of $\mathrm{p}^{2} \mathrm{1}^{\text {ras }}$ similar to that observed with insulin (Fig. 1A). This is not a consequence of overexpression of the insulin receptor, since EGF stimulation resulted in ras activation in the H13 cell line (Fig. 1A) and the parental Rat-1 cell line as well (Fig. 1C). Furthermore, we compared the time course of ras activation in A14 cells with that in H13IR2000 cells in response to insulin (Fig. 1B) as well as the time course in Rat-1 cells with that in H13IR2000 cells in response to EGF (Fig. 1C). Activation of p21 ras follows a pattern in H13IR2000 cells similar to that in A14 or Rat-1, with the minor difference being that the time required to reach half-maximal stimulation of ras activation in H13IR2000 cells is somewhat longer than that in A14 cells (Fig. 1B) and in Rat-1 cells (Fig. 1C). Considering the approximately 100 -fold-higher expression of p21 ras in H13IR2000 cells, this suggests that the activation of $\mathrm{p} 21^{\text {ras }}$ by insulin or EGF is not affected by the high levels of p21 H-ras in the H13IR2000 cell line.

Increased nucleotide exchange on $\mathbf{p 2}^{\text {ras }}$. To determine whether the activation of $21^{\text {ras }}$ by insulin and EGF in H13IR2000 cells is caused by an increase in the rate of nucleotide exchange on $21^{r a s}$, we measured binding of $\left[\alpha^{-32} \mathrm{P}\right] \mathrm{GTP}$ to $\mathrm{p} 21^{\text {ras }}$ in permeabilized H13IR2000 cells. Cells were stimulated with either EGF for 2 min or insulin for $5 \mathrm{~min}$, permeabilized with streptolysin $\mathrm{O}$, and incubated with $\left[\alpha-{ }^{32} \mathbf{P}\right]$ GTP. At different time points, cells were lysed and p $21^{\text {ras }}$ was collected by immunoprecipitation. Nucleotides bound to p21 ras were eluted and separated by TLC. Nucleotide binding to p21 ras in H13IR2000 cells was enhanced approximately threefold in response to insulin and EGF compared with that in untreated cells (Fig. 2). Stimulation with the phorbol ester 12-O-tetradecanoylphorbol-13acetate had no effect on nucleotide binding to $\mathrm{p} 21^{\text {ras }}$, which is consistent with the finding that $12-\mathrm{O}$-tetradecanoylphorbol-13-acetate has no effect on the activation state of p21 ras in intact H13IR2000 cells (data not shown). The same difference in nucleotide binding in response to insulin could also be observed after immunoprecipitation with another monoclonal antibody directed against p21 ras, Y13-238 (data not shown).

No significant shift in the GDP/GTP ratio bound to $221^{\text {ras }}$ was observed in permeabilized cells after stimulation with insulin or EGF, whereas similar stimulation leads to accumulation of GTP on p $21^{\text {ras }}$ of up to $50 \%$ of the total bound nucleotide in intact cells. This difference could be caused by hydrolysis of GTP on p21 ras or due to hydrolysis of GTP prior to binding to $21^{\text {ras }}$ in permeabilized cells. To discriminate between these two possibilities, we used the RR3 cell
A.
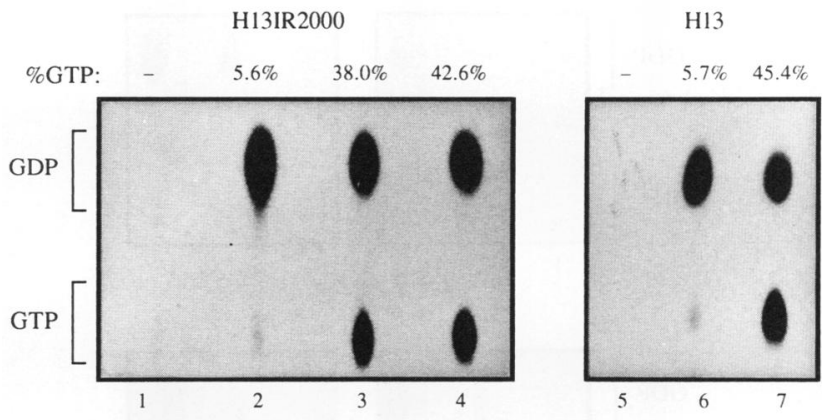

B.

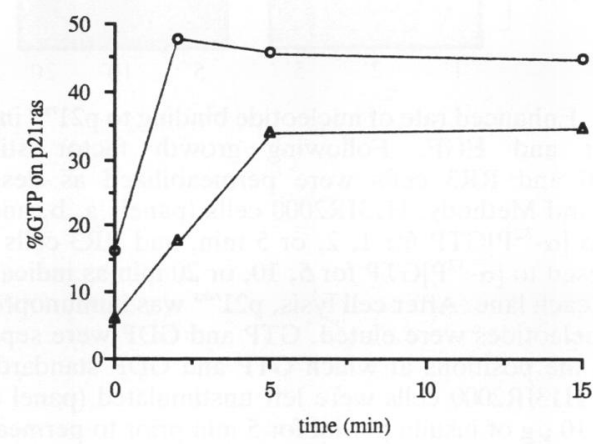

C.

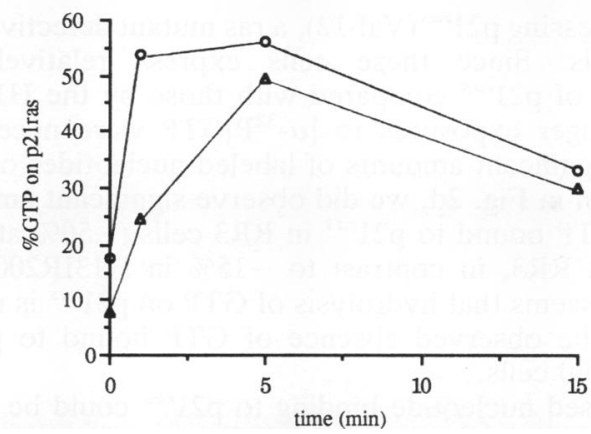

FIG. 1. Activation of $\mathrm{p} 21^{\text {ras }}$ by insulin and EGF in fibroblasts. A14, Rat-1, H13, and H13IR2000 cells were labeled with ${ }^{32} P_{i}$ as described in Materials and Methods. Cells were lysed, and $\mathrm{p} 21^{\text {ras }}$ was immunoprecipitated. Nucleotides bound to $\mathrm{p}^{2} \mathrm{r}^{\text {ras }}$ were eluted and separated by TLC. Following autoradiography, spots corresponding to GTP and GDP were cut out and counted by scintillation counting. (A) TLC of the guanine nucleotides eluted from p21 ras immunoprecipitates from H13IR2000 cells (lanes 1 to 4 ) or H13 cells (lanes 5 to 7). Immunoprecipitation was performed with the monoclonal antibody Y13-259 (lanes 2, 3, 4, 6, and 7) or with the nonrelated antibody kT3, which is unable to recognize p21 ras (lanes 1 and 5). Cells were unstimulated (lanes $1,2,5$, and 6), stimulated with $10 \mu \mathrm{g}$ of insulin per $\mathrm{ml}$ for $5 \mathrm{~min}$ (lane 3), or stimulated with $20 \mathrm{ng}$ of EGF per $\mathrm{ml}$ for $5 \mathrm{~min}$ (lanes 4 and 7). Indicated are the positions at which GTP and GDP standards ran. At the top of each lane, the amount of GTP (as a percentage of total nucleotide bound to $\mathrm{p} 21^{\text {ras }}$ ) is indicated. (B) Time course of ras activation in response to insulin in A14 and H13IR2000 cells. A14 cells $(O)$ or H13IR2000 cells $(\triangle)$ were stimulated with $10 \mu \mathrm{g}$ of insulin per $\mathrm{ml}$ for 2,5 , or $15 \mathrm{~min}$. (C) Time course of ras activation in response to EGF in Rat-1 and H13IR2000 cells. Rat-1 $(O)$ or H13IR2000 cells $(\Delta)$ were stimulated with $20 \mathrm{ng}$ of EGF per ml for 2, 5 , or $15 \mathrm{~min}$. The percentage of GTP is expressed as relative to the total amount of labeled nucleotide bound to p21 ${ }^{\text {ras }}$. 

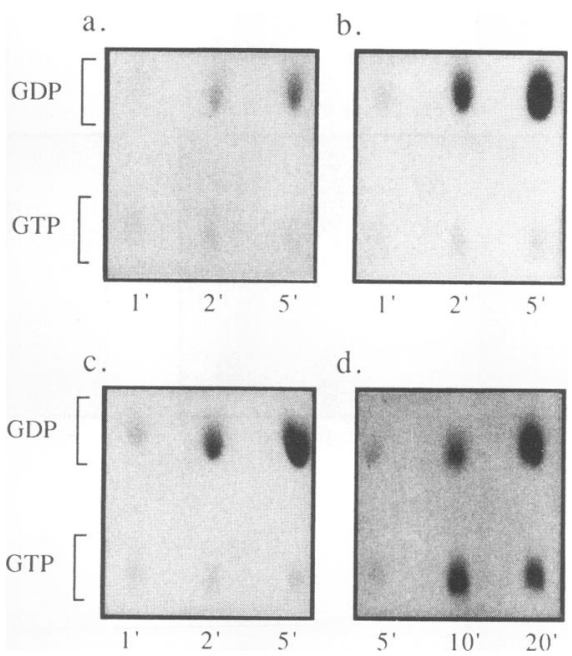

FIG. 2. Enhanced rate of nucleotide binding to $\mathrm{p} 21^{\text {ras }}$ in response to insulin and EGF. Following growth factor stimulation, H13IR2000 and RR3 cells were permeabilized as described in Materials and Methods. H13IR2000 cells (panels a, b, and c) were exposed to $\left[\alpha^{32} \mathrm{P}\right] \mathrm{GTP}$ for 1,2 , or $5 \mathrm{~min}$, and RR3 cells (panel d) were exposed to $\left[\alpha_{-}{ }^{32} \mathrm{P}\right] \mathrm{GTP}$ for 5,10 , or $20 \mathrm{~min}$ as indicated at the bottom of each lane. After cell lysis, p21 ${ }^{\text {ras }}$ was immunoprecipitated and the nucleotides were eluted. GTP and GDP were separated by TLC, and the positions at which GTP and GDP standards ran are indicated. H13IR2000 cells were left unstimulated (panel a), stimulated with $10 \mu \mathrm{g}$ of insulin per $\mathrm{ml}$ for $5 \mathrm{~min}$ prior to permeabilization (panel b), or stimulated with $20 \mathrm{ng}$ of EGF per $\mathrm{ml}$ for $2 \mathrm{~min}$ prior to permeabilization (panel c). RR3 cells were left unstimulated (panel d).

line expressing p21 ras (Val-12), a ras mutant defective in GTP hydrolysis. Since these cells express relatively small amounts of p21 ras compared with those by the H13IR2000 cells, longer exposures to $\left[\alpha-{ }^{32} \mathrm{P}\right] \mathrm{GTP}$ were necessary to obtain significant amounts of labeled nucleotides on p21 ras. As shown in Fig. 2d, we did observe significant amounts of $\left[\alpha-{ }^{32} \mathrm{P}\right]$ GTP bound to $21^{\text {ras }}$ in RR3 cells $(\sim 50 \%$ at all time points in RR3, in contrast to $\sim 15 \%$ in H13IR2000 cells). Thus, it seems that hydrolysis of GTP on p21 ras is responsible for the observed absence of GTP bound to $\mathrm{p} 21^{\text {ras }}$ in H13IR2000 cells.

Increased nucleotide binding to $\mathrm{p} 21^{\text {ras }}$ could be the consequence of an increased rate of binding or increased overall binding. We therefore compared the kinetics of binding of nucleotides to $\mathrm{p} 21^{\text {ras }}$ in stimulated cells with that in unstimulated cells. To minimize variations in the specific activities in these experiments, $10 \mu \mathrm{M}$ unlabeled GTP was added to the permeabilization buffer. After stimulation with insulin, a clear twofold increase was consistently observed in the initial rate of nucleotide binding to p21 ras (Fig. 3A). Nucleotide binding to $21^{\text {ras }}$ in insulin-stimulated cells approached plateau levels after $20 \mathrm{~min}$, whereas binding in unstimulated cells was still submaximal. This indicates that increased binding is due to an increased rate of binding and is not a consequence of an increased number of binding sites available for $\left[\alpha-{ }^{32} \mathrm{P}\right]$ GTP. To exclude the possibility that insulin stimulation might affect the efficiency of permeabilization or the uptake of $\left[\alpha{ }^{32} P\right]$ GTP into permeabilized cells, we measured binding of $\left[\alpha^{-32} \mathrm{P}\right]$ GTP to total cellular proteins, which was determined by filter binding on nitrocellulose filters. Total binding of $\left[\alpha^{-32} \mathrm{P}\right] \mathrm{GTP}$ in permeabilized cells was unaltered in the presence of insulin compared with that in unstimulated cells (Fig. 3B).
In addition, we measured the rate at which labeled guanine nucleotides bound to p $21^{\text {ras }}$ are replaced by unlabeled nucleotide after the addition of excess unlabeled GTP (1 mM). For this purpose, permeabilized cells were exposed to $3 \mathrm{nM}$ $\left[\alpha{ }^{32} \mathrm{P}\right]$ GTP for $10 \mathrm{~min}$, followed by a cold chase with $1 \mathrm{mM}$ unlabeled GTP. Eighty percent of the labeled nucleotide bound to p21 ras in cells stimulated with insulin was released within $1 \mathrm{~min}$, showing the specificity of the binding (Fig. 3C). However, a certain proportion of the labeled nucleotide has a much slower off rate. This could either result from a slow intrinsic exchange of guanine nucleotides on $\mathrm{p} 21^{\text {ras }}$ or represent aspecific binding.

Inhibition of ras activation by expression of ras(Asn-17). To examine the involvement of guanine nucleotide exchange factors in more detail, we used a dominant negative mutant of $\mathrm{p} 21^{\text {ras }}$, ras(Asn-17). This mutant has a low affinity for GTP, and as a consequence it will predominantly bind GDP (20). Inhibition of ras function by this mutant presumably takes place through competition for activators of $\mathrm{p}^{\text {ras }}$. Therefore, we investigated whether the activation of $\mathrm{p}^{2} 1^{\text {ras }}$ in intact cells can be blocked by the expression of this mutant $\mathrm{p} 21^{\text {ras }}$. For this purpose, cells were infected with a recombinant vaccinia virus containing the ras(Asn-17) mutant gene (16). After infection with ras(Asn-17) recombinant vaccinia virus, approximately $100 \%$ of the cells express ras(Asn-17) protein, since the activation of extracellular signal-regulated kinase 2 (ERK2) by insulin is completely inhibited (16). Sixteen to $18 \mathrm{~h}$ after infection, cells were labeled with ${ }^{32} \mathrm{P}_{\mathrm{i}}$ for $4 \mathrm{~h}$, and labeling was followed by an analysis of the GTP/GDP ratio bound to $\mathrm{p} 21^{\text {ras }}$. As a control for the effects of viral infection, cells were infected with wild-type vaccinia virus. The lysates were incubated with $\mathrm{Ni}^{2+}$-NTA agarose to remove recombinant ras(Asn-17) protein prior to being immunoprecipitated. Incubation with $\mathrm{Ni}^{2+}$-NTA agarose for $15 \mathrm{~min}$ removed all recombinant ras(Asn-17) protein, since a second incubation with $\mathrm{Ni}^{2+}$. NTA agarose could not detect any remaining ras(Asn-17) protein (Fig. 4). Therefore, ras(Asn-17) protein will not contribute to the nucleotide ratio bound to $\mathrm{p} 21^{\text {ras }}$ immunoprecipitates. In addition, the expression level of $\mathrm{p} 21^{\text {ras }}$ (Asn17) was estimated to be at least 20 -fold lower than that of endogenous wild-type p21 ras in H13IR2000 cells (Fig. 4). Insulin- and EGF-induced activation of p21 ras occurred normally in H13IR2000 cells infected with wild-type virus (Fig. 5). However, the activation of $\mathrm{p} 21^{\text {ras }}$ by both insulin and EGF was inhibited ( 85 and $50 \%$ inhibition, respectively) in cells infected with the recombinant ras(Asn-17) vaccinia virus (Fig. 5). Autophosphorylation of the insulin receptor occurred normally in these cells, as judged from immunoprecipitates with an anti-phosphotyrosine antibody (data not shown).

Inhibition of increased nucleotide binding by expression of ras(Asn-17). If activation of $\mathrm{p} 21^{\text {ras }}$ by insulin or EGF occurs through activation of an exchange factor for $\mathrm{p} 21^{\text {ras }}$, as suggested by our findings, then the activation of nucleotide exchange by these growth factors should be sensitive to expression of ras(Asn-17). We investigated the effects of insulin and EGF on the binding rate of labeled nucleotides to p $21^{\text {ras }}$ in cells infected with the ras(Asn-17) recombinant vaccinia virus. The increased binding rate observed in response to insulin was inhibited in cells expressing ras(Asn17) (77 to $100 \%$ inhibition; Fig. 6). The increased binding rate induced by EGF was also inhibited by ras(Asn-17) $(55 \%$ inhibition) (not shown). This indicates that the enhanced binding rate in response to insulin and EGF is due to the activation of a guanine nucleotide exchange factor. How- 

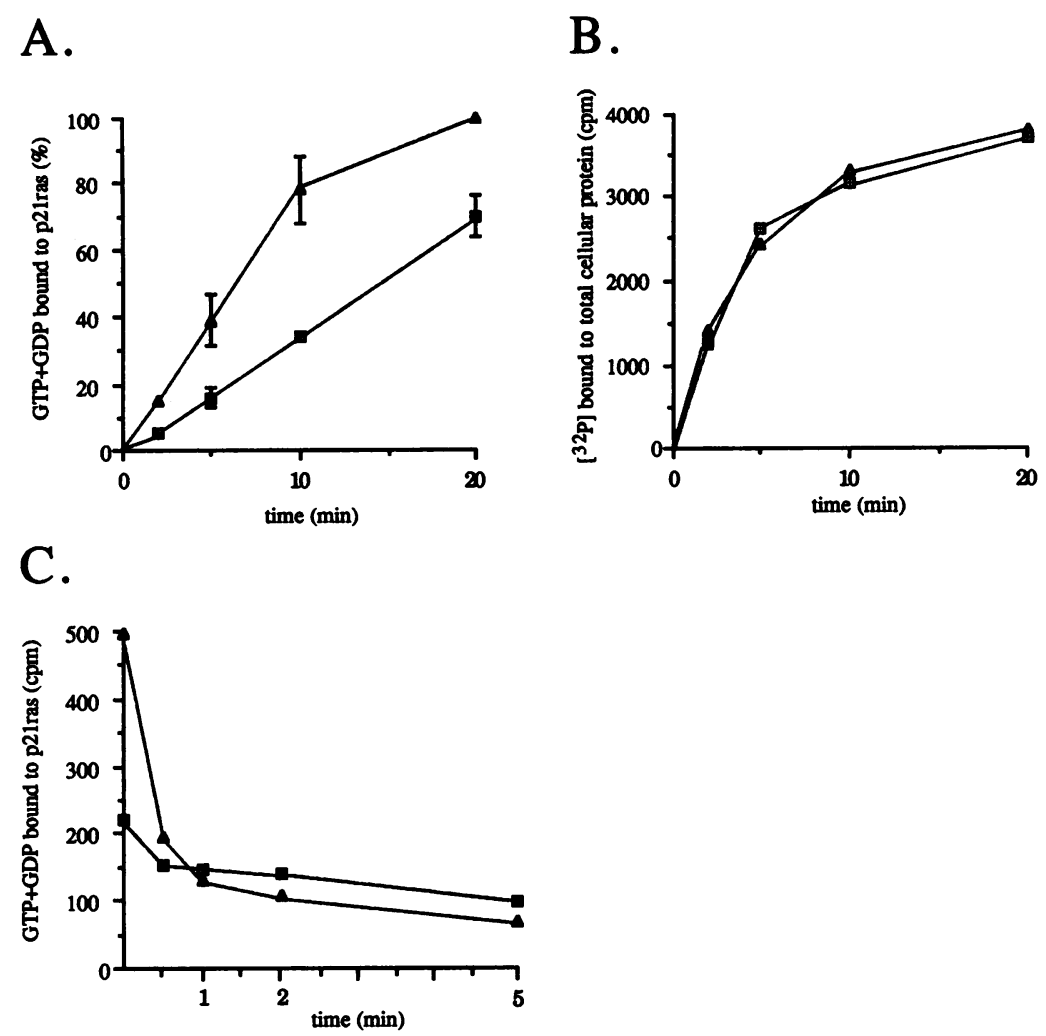

FIG. 3. Binding of $\left[\alpha^{-32} \mathrm{P}\right]$ GTP to $21^{\text {ras }}$ and total cellular proteins. H13IR2000 cells were left unstimulated (פ) or were stimulated with 10 $\mu \mathrm{g}$ of insulin per $\mathrm{ml}$ for $5 \mathrm{~min}(\triangle)$. Cells were permeabilized and exposed to [ $\left.\alpha-{ }^{32} \mathrm{P}\right] \mathrm{GTP}$ for various lengths of time. [ $\left.\alpha-{ }^{32} \mathrm{P}\right] \mathrm{GTP}$ was diluted with unlabeled GTP to $10 \mu \mathrm{M}$ for measurement of binding to p21 ras and total cellular proteins. Following lysis and Triton X-114 phase separation, p21 ras was immunoprecipitated from the detergent phase as usual, and a 100- $\mu$ l fraction of the aqueous phase was used for filter binding. (A) Binding of $\alpha-{ }^{32} \mathrm{P}$-labeled guanine nucleotides to immunoprecipitates of $\mathrm{p} 21^{\text {ras }}$ expressed as the percentage of the amount of binding to p21 ras observed at 20 min in stimulated cells (set at 100\%). Each point represents the average of four separate measurements, and error bars indicate standard deviations. (B) Binding of $\left[\alpha{ }^{32}\right.$ P]GTP to total cellular proteins in lysates from unstimulated or insulin-stimulated H13IR2000 cells as determined in a filter-binding assay. (C) Unstimulated or insulin-stimulated H13IR2000 cells were permeabilized and exposed to $3 \mathrm{nM}\left[\alpha{ }^{32} \mathrm{P}\right] \mathrm{GTP}$ for $10 \mathrm{~min}$. A chase was performed by the addition of excess unlabeled GTP (1 mM). At different time points after the addition of unlabeled GTP, cells were lysed and p21 ras was immunoprecipitated. The amount of $\alpha-{ }^{32} \mathrm{P}$-labeled nucleotide retained on immunoprecipitates of p21 2 ras was determined as described in the legend to Fig. 2.

ever, the unstimulated binding rate was almost unaltered in the presence of $\mathrm{p}^{\text {ras }}$ (Asn-17) (Fig. 6), suggesting that a large fraction of this binding occurs through a different mechanism.

\section{DISCUSSION}

Stimulation of tyrosine kinase receptors, including EGF and insulin receptors, activates $\mathrm{p} 21^{\text {ras }}$ as measured by an increase in GTP-bound p21 ras. In this report, we demonstrate that this increase in the GTP-bound form of p21 ras is, at least in part, due to enhanced guanine nucleotide exchange. To study guanine nucleotide exchange on p21 ras, we have used a Rat-1-derived cell line expressing elevated levels of p21 H-ras (H13) as well as an $\mathrm{H} 13$ cell line transfected with the human insulin receptor (H13IR2000). Both insulin and EGF induce activation of $\mathrm{p}^{2} 1^{\text {ras }}$ in this latter cell line. Treatment of H13IR2000 cells with insulin or EGF caused an increase of GTP-bound p $21^{\text {ras }}$, from $\sim 7 \%$ of the total nucleotide bound to p21 ras in unstimulated cells to $\sim 40 \%$ in insulin- or EGF-stimulated cells (Fig. 1A). Since the time course of ras activation in response to insulin or EGF followed similar patterns in H13IR2000 cells and A14 or Rat-1 cells, respectively (Fig. $1 B$ and C), it seems unlikely

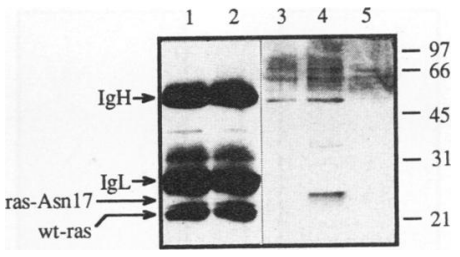

FIG. 4. Expression of wild-type $\mathrm{p} 21^{\text {ras }}$ and recombinant ras(Asn17) proteins in vaccinia virus-infected cells. H13IR2000 cells were infected with wild-type vaccinia virus (lanes 1 and 3) or ras(Asn-17) recombinant vaccinia virus (lanes 2,4 , and 5), and 16 to $18 \mathrm{~h}$ after infection, cells were harvested. Lysates were precleared with $\mathrm{Ni}^{2+}$. NTA agarose to bind recombinant ras(Asn-17) protein (lanes 3 and 4), and preclearance was followed by immunoprecipitation of the remaining $\mathrm{p}^{2} 1^{\text {nas }}$ with $\mathrm{Y} 13-259$ bound to protein A agarose beads (lanes 1 and 2 ) or by a second incubation with $\mathrm{Ni}^{2+}$-NTA agarose (lane 5). $\mathrm{Ni}^{2+}$-NTA agarose beads and $\mathrm{p} 21^{\text {ras }}$ immunoprecipitates were boiled in sample buffer and loaded onto a $15 \%$ polyacrylamide gel. Ras proteins were detected as described in Materials and Methods. Exposure of the blot for detection of the ras(Asn-17) protein bound to $\mathrm{Ni}^{2+}$-NTA agarose beads was 10 times longer than that for detection of p21 ras bound to Y13-259. Due to the presence of 6 histidine residues at the amino-terminal end, ras(Asn-17) has a slightly slower mobility than wild-type $\mathrm{p} 21^{\text {ras }}$. The positions of molecular size markers (in kilodaltons) are indicated on the right. 

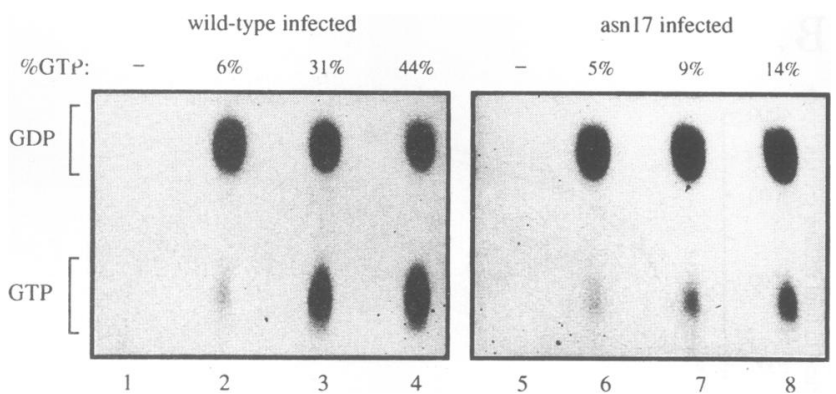

FIG. 5. Activation of p21 ras inhibited by ras(Asn-17). H13IR2000 cells were infected with wild-type vaccinia virus (left panel) or with the ras(Asn-17) recombinant vaccinia virus (right panel). Eighteen hours after transfection, cells were labeled with ${ }^{32} \mathbf{P}_{\mathrm{i}}$. Following growth factor stimulation, cells were lysed, ras(Asn-17) recombinant protein was removed with $\mathrm{Ni}^{2+}$-NTA agarose, and $\mathrm{p} 21^{\text {ras }}$ was immunoprecipitated. Nucleotides were eluted from immunoprecipitates of p21 ras and separated by TLC. The cells were left unstimulated (lanes $1,2,5$, and 6), stimulated with $10 \mu \mathrm{g}$ of insulin per $\mathrm{ml}$ for $5 \mathrm{~min}$ (lanes 3 and 7), or stimulated with $20 \mathrm{ng}$ of EGF per $\mathrm{ml}$ for $5 \mathrm{~min}$ (lanes 4 and 8). Control immunoprecipitations were performed with the nonrelated antibody kT3 (lanes 1 and 5). The percentage of GTP bound to p2 $1^{\text {ras }}$ relative to the total amount of bound nucleotide (GTP plus GDP) is indicated at the top of each lane.

that overexpression of p21 H-ras has a profound effect on the mechanism of ras activation.

To study the effect of growth factor stimulation on nucleotide exchange on p21 ras, H13IR2000 cells were used to measure GTP binding to p $21^{\text {ras }}$ in permeabilized cells. Binding of $\left[\alpha-{ }^{32} \mathrm{P}\right] \mathrm{GTP}$ to $\mathrm{p} 21^{\text {ras }}$ in permeabilized H13IR2000 cells was enhanced in response to insulin and EGF (Fig. 2), but not by 12-O-tetradecanoylphorbol-13-acetate, consistent with the effect of each of these growth factors on the activation state of $\mathrm{p}^{2} 1^{\text {ras }}$ in intact cells. An increase of approximately two- to threefold was consistently observed wild-type infected

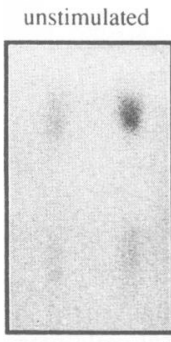

$2^{\prime} \quad 5^{\prime}$

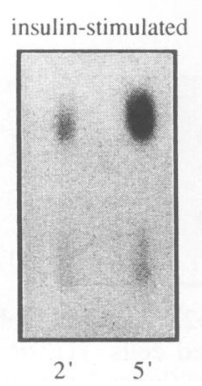

asn 17 infected

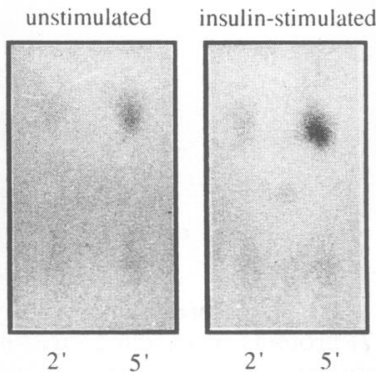

FIG. 6. Inhibition of enhanced nucleotide binding by ras(Asn17). H13IR2000 cells were infected with wild-type (left panel) or ras(Asn-17) recombinant (right panel) vaccinia virus. Sixteen to $18 \mathrm{~h}$ after transfection, cells were permeabilized with streptolysin $O$ and exposed to $\left[\alpha-{ }^{32} \mathrm{P}\right] \mathrm{GTP}$. After 2 or $5 \mathrm{~min}$, cells were lysed, ras(Asn17) recombinant protein was removed with $\mathrm{Ni}^{2+}$-NTA agarose, and p21 ${ }^{\text {ras }}$ was immunoprecipitated. Cells were left unstimulated or were stimulated with $10 \mu \mathrm{g}$ of insulin per $\mathrm{ml}$ for $5 \mathrm{~min}$ prior to permeabilization, where indicated. The amount of total labeled nucleotide bound to $\mathrm{p}^{2} 1^{\text {ras }}$ was determined as described in the legend to Fig. 3. Inhibition of insulin-induced nucleotide binding in cells expressing p21 ${ }^{\text {ras }}$ (Asn-17) was reproduced in three separate experiments, with 77,100 , and $100 \%$ inhibition, respectively. We also observed similar inhibition $(55 \%)$ in the rate of EGF-induced nucleotide binding in two independent experiments. in the initial rate of guanine nucleotide binding to $\mathrm{p} 21^{\text {ras }}$ after stimulation with insulin (Fig. 3A). Since growth factor stimulation had no effect on the binding of labeled nucleotides to total cellular proteins (Fig. 3B), we conclude that the increased rate of nucleotide binding in cells treated with insulin or EGF is not the consequence of a difference in uptake of $\left[\alpha^{-32} \mathrm{P}\right] \mathrm{GTP}$ or efficiency of permeabilization. Therefore, the observed difference reflects a real difference in the binding rate of guanine nucleotides to $\mathrm{p} 21^{\text {ras }}$, presumably through activation of a guanine nucleotide exchange factor.

This latter notion was further strengthened by the experiments performed with a dominant negative mutant of $\mathrm{p} 21^{\text {ras }}$, p21 ${ }^{\text {ras }}$ (Asn-17). This mutant has a 40-fold-reduced affinity for GTP, but its affinity for GDP is unaltered (20). Inhibition of endogenous ras function by this mutant has been proposed to occur through competition with normal ras for regulatory proteins which normally promote nucleotide exchange (20). Indeed, we found that the introduction of $\mathrm{p} 21^{\text {ras }}$ (Asn-17) almost completely inhibited insulin- and EGF-induced activation of $\mathrm{p}^{2} 1^{\text {ras }}$ in intact cells (Fig. 5). This finding constitutes the first direct proof that $\mathrm{p} 21^{\text {ras }}$ (Asn-17) actually inhibits p21 ras activation. Remarkably, up to $85 \%$ inhibition can be accomplished, although the expression level of p21 ras (Asn-17) in H13IR2000 cells infected with ras(Asn-17) recombinant virus is at least 20 -fold lower than that of wild-type p21 ras (Fig. 4). Clearly, p21 ras (Asn-17) is a very efficient inhibitor of $\mathrm{p} 21^{\text {ras }}$, suggesting a very high affinity of ras(Asn-17) for the exchange factor.

The increased rate of nucleotide binding in response to insulin and EGF was also inhibited by expression of ras(Asn-17) (Fig. 6). In contrast, unstimulated nucleotide exchange was only slightly affected by $\mathrm{p}^{2} 1^{\text {ras }}$ (Asn-17). Remarkably, the extent of inhibition of increased nucleotide binding in response to insulin (77 to $100 \%)$ or EGF $(55 \%)$ is similar to the level of inhibition of insulin- $(85 \%)$ and EGF-induced $(50 \%)$ activation of p21 ras in intact cells. In conclusion, our findings that $\mathrm{p} 21^{\text {ras }}$ (Asn-17) inhibits both ras activation in intact cells and growth factor-induced nucleotide binding to $\mathrm{p} 21^{\text {ras }}$ in permeabilized cells to similar extents suggest that the activation of a nucleotide exchange factor is involved in the activation of $\mathrm{p} 21^{\text {ras }}$ by insulin and EGF.

Virtually all of the labeled nucleotide bound to $\mathrm{p} 21^{\text {ras }}$ after stimulation with insulin could be released by the addition of excess unlabeled GTP (Fig. 3C), stressing the specificity of the nucleotide binding. However, a certain proportion of the labeled nucleotide is released very slowly during the chase experiment. This fraction can be more than $50 \%$ of the total amount of labeled nucleotide recovered from ras immunoprecipitates in the unstimulated cells (Fig. 3C). The slow release could be caused by a fraction of $\mathrm{p} 21^{\text {ras }}$ which is not in contact with an exchange factor and thus represent intrinsic exchange of nucleotides on p21 ${ }^{\text {ras }}$, or it could be due to aspecific binding. This would suggest that a certain proportion of labeled nucleotide is bound to $\mathrm{p} 21^{\text {ras }}$ in a manner independent of a guanine nucleotide exchange factor. In turn, this would explain why unstimulated binding of nucleotides to $\mathrm{p} 21^{\text {ras }}$ is hardly affected by expression of ras(Asn-17). If so, then the guanine nucleotide exchange factor per se is activated more than two- to threefold by EGF or insulin.

Although the release of labeled nucleotides from $\mathrm{p} 21^{\text {ras }}$ is virtually complete within $1 \mathrm{~min}$ after the addition of $1 \mathrm{mM}$ GTP in insulin-stimulated cells (Fig. 3C), it takes at least 20 min for binding of labeled nucleotides to $\mathrm{p} 21^{\text {ras }}$ to reach 
steady-state levels in these cells in the presence of $10 \mu \mathrm{M}$ GTP (Fig. 3A). Thus, the measured off rate of nucleotides bound to $221^{\text {ras }}$ is higher than the measured on rate. Possibly, either the release of GDP or the binding of GTP is dependent on the concentration of GTP, and the observed difference in on and off rates is due to the different concentrations of GTP used in each experiment $(10 \mu \mathrm{M}$ for binding, $1 \mathrm{mM}$ for release).

Unlike with intact cells, no accumulation of GTP-bound $\mathrm{p} 21^{\text {ras }}$ is observed in permeabilized cells after stimulation with insulin or EGF (compare Fig. 1 and 2). However, $\left[\alpha-{ }^{32} \mathrm{P}\right] \mathrm{GTP}$ is sufficiently stable in the permeabilized cells to obtain significant amounts of ras GTP in cells that express a mutated ras protein which is unable to hydrolyze GTP (RR3) (Fig. 2). Thus, it seems that hydrolysis of GTP on p21 $1^{\text {ras }}$ is responsible for the observed absence of GTP bound to p $21^{\text {ras }}$ in H13IR2000 cells. In our view, this difference between intact and permeabilized cells is best explained by the forementioned observation that the on rate might be limited by the availability of GTP in the experiments using permeabilized cells. A submaximal exchange rate in permeabilized cells would result in the absence of GTP bound to p21 ${ }^{\text {ras }}$. This also explains why our results differ from those of experiments using permeabilized $T$ cells, in which a clear increase in the level of GTP bound to p21 ras after T-cell receptor stimulation has been previously observed (18). In these cells, regulation of the activation state of $\mathrm{p} 21^{\text {ras }}$ has been previously proposed to occur through inhibition of GAP activity (18), which is in contrast to the mechanism proposed here for the regulation of ras activation in fibroblasts. This inhibition of GAP activity may permit the detection of GTP bound to $21^{\text {ras }}$ from permeabilized T cells. In fibroblasts, a reduction in GTPase stimulatory properties in response to insulin or EGF has not been observed thus far $(5,11)$. However, a role for p120GAP in the regulation of p $21^{\text {ras }}$ in fibroblasts cannot be excluded at this point, considering that p120GAP interacts with all tyrosine kinase receptors known to activate $21^{\text {ras }}(28,31,39)$. Moreover, EGF stimulation has been previously reported to induce association of p120GAP with a $190-\mathrm{kDa}$ phosphoprotein, which results in a fourfold reduction in GAP activity (36). Similarly, in $\mathrm{T}$ cells the additional involvement of induced exchange cannot be excluded. It could be that both the rate of nucleotide exchange on $\mathrm{p}^{2} \mathrm{1}^{\text {ras }}$ and the rate of GTP hydrolysis are changed upon growth factor stimulation. Therefore, the apparent difference in regulation of the activation state of $\mathrm{p} 21^{\text {ras }}$ in $\mathrm{T}$ lymphocytes and fibroblasts may be a consequence of the relative contribution of each of the two mechanisms. Regulation of both nucleotide exchange on p $21^{\text {ras }}$ as well as GTPase activity of p $21^{\text {ras }}$ has recently been suggested to occur in PC12 cells stimulated with nerve growth factor. Remarkably, an increase in GTPase stimulatory activity appears to antagonize the measured increase in activity of the nucleotide exchange factor (30). Also, by using a more indirect approach with a number of mutants of p21 ras introduced in NIH 3T3 cells, it was previously shown that serum- and platelet-derived growth factors most likely stimulate guanine nucleotide exchange, whereas the p21 ras GTPase activity seems to be affected by cell density (53). Taken together, these data strongly suggest that the activity of the exchange factor(s) for $\mathrm{p} 21^{\text {ras }}$ is regulated by growth factors, leading to the activation of $\mathrm{p} 21^{\text {ras }}$. The mechanism by which these growth factors activate the exchange factor(s) remains to be elucidated.

\section{ACKNOWLEDGMENTS}

We thank Julian Downward for discussions. Also, we thank our colleagues in the laboratory, Boudewijn Burgering, Jan Paul Medema, Bert Pronk, and Loesje van der Voorn, for helpful discussions and critically reading the manuscript.

This work was supported in part by the Dutch Cancer Society.

\section{REFERENCES}

1. Ballester, R., D. Marchuk, M. Boguski, A. Saulino, R. Letcher, M. Wigler, and F. Collins. 1990. The NF1 locus encodes a protein functionally related to mammalian GAP and yeast IRA proteins. Cell 63:851-859.

2. Barbacid, M. 1987. ras genes. Annu. Rev. Biochem. 56:779_ 827.

3. Basu, T. N., D. H. Gutmann, J. A. Fletcher, T. W. Glover, F. S. Collins, and J. Downward. 1992. Aberrant regulation of ras proteins in malignant tumor cells from type 1 neurofibromatosis patients. Nature (London) 356:713-715.

4. Bollag, G., and F. McCormick. 1991. Differential regulation of rasGAP and neurofibromatosis gene product activities. Nature (London) 351:576-579.

5. Bollag, G., and F. McCormick. 1992. Personal communication.

6. Bonfini, L., C. A. Karlovich, C. Dasgupta, and U. Banerjee. 1992. The Son of sevenless gene product: a putative activator of Ras. Science 255:603-606.

7. Bourne, H. R., D. A. Sanders, and F. McCormick. 1990. The GTPase superfamily: a conserved switch for diverse cell functions. Nature (London) 348:125-132.

8. Bourne, H. R., D. A. Sanders, and F. McCormick. 1990. The GTPase superfamily: conserved structure and molecular mechanism. Nature (London) 349:117-127.

9. Broek, D., T. Toda, T. Michaeli, L. Levin, C. Birchmeier, M. Zoller, S. Powers, and M. Wigler. 1987. The S. cerevisiae $C D C 25$ gene product regulates the $R A S$ /adenylate cyclase pathway. Cell 48:789-799.

10. Buller, R. M. L., S. Chakrabarti, J. A. Cooper, D. R. Twardzik, and B. Moss. 1988. Deletion of the vaccinia virus growth factor gene reduces virus virulence. J. Virol. 62:866-874.

11. Burgering, B. M. T., and J. L. Bos. 1992. Unpublished observations.

12. Burgering, B. M. T., R. H. Medema, J. A. Maassen, M. L. van de Wetering, A. J. van der Eb, F. McCormick, and J. L. Bos. 1991. Insulin stimulation of gene expression mediated by p21ras activation. EMBO J. 10:1103-1109.

13. Burgering, B. M. T., A. J. Snijders, J. A. Maassen, A. J. van der Eb, and J. L. Bos. 1989. Possible involvement of normal p21 H-ras in the insulin/insulinlike growth factor 1 signal transduction pathway. Mol. Cell. Biol. 9:4312-4322.

14. Cai, H., J. Szeberényi, and G. M. Cooper. 1990. Effect of a dominant inhibitory Ha-ras mutation on mitogenic signal transduction in NIH 3T3 cells. Mol. Cell. Biol. 10:5314-5323.

15. Créchet, J.-B., P. Poullet, M.-Y. Mistou, A. Parmeggiani, J. Camonis, E. Boy-Marcotte, F. Damak, and M. Jacquet. 1990. Enhancement of the GDP-GTP exchange of RAS proteins by the carboxyl-terminal domain of SCD25. Science 248:866-868.

16. de Vries-Smits, A. M. M., B. M. T. Burgering, S. J. Leevers, C. J. Marshall, and J. L. Bos. 1992. Involvement of p21ras in activation of extracellular signal-regulated kinase 2. Nature (London) 357:602-604.

17. Downward, J., J. De Gunzburg, R. Riehl, and R. A. Weinberg. 1988. p21ras-induced responsiveness of phosphatidylinositol turnover to bradykinin is a receptor number effect. Proc. Natl. Acad. Sci. USA 85:5774-5778.

18. Downward, J., J. D. Graves, P. H. Warne, S. Rayter, and D. A. Cantrell. 1990. Stimulation of $\mathrm{p}^{\text {ras }}$ upon T-cell activation. Nature (London) 346:719-723.

19. Downward, J., R. Riehl, L. Wu, and R. A. Weinberg. 1990. Identification of a nucleotide exchange-promoting activity for p21 ${ }^{\text {ras }}$. Proc. Natl. Acad. Sci. USA 87:5998-6002.

20. Feig, L. A., and G. M. Cooper. 1988. Inhibition of NIH 3T3 cell proliferation by a mutant ras protein with preferential affinity for GDP. Mol. Cell. Biol. 8:3235-3243.

21. Feramisco, J. R., M. Gross, T. Kamata, M. Rosenberg, and 
R. W. Sweet. 1984. Microinjection of the oncogenic form of the human H-ras (T24) protein results in rapid proliferation of quiescent cells. Cell 38:109-117.

22. Gaul, U., G. Mardon, and G. M. Rubin. 1992. A putative ras GTPase activating protein acts as a negative regulator of signaling by the sevenless receptor tyrosine kinase. Cell 68:10071019.

23. Gibbs, J. B., M. S. Marshall, E. M. Scolnick, R. A. F. Dixon, and U. S. Vogel. 1990. Modulation of guanine nucleotides bound to ras in NIH3T3 cells by oncogenes, growth factors, and the GTPase activating protein (GAP). J. Biol. Chem. 265:2043720442.

24. Gutierrez, L., A. I. Magee, C. J. Marshall, and J. F. Hancock. 1989. Post-translational processing of p21ras is two-step and involves carboxyl-methylation and carboxy-terminal proteolysis. EMBO J. 8:1093-1098.

25. Hall, A. 1990. The cellular functions of small GTP-binding proteins. Science 249:635-640.

26. Janknecht, R., G. de Martynof,, J. Lou, R. A. Hipskind, A. Nordheim, and H. G. Stunnenberg. 1991. Rapid and efficient purification of native histidine-tagged protein expressed by recombinant vaccinia virus. Proc. Natl. Acad. Sci. USA 88: 8972-8976.

27. Kamata, T., and J. R. Feramisco. 1984. Epidermal growth factor stimulates guanine nucleotide binding activity and phosphorylation of ras oncogene proteins. Nature (London) 310:147-150.

28. Kazlauskas, A., C. Ellis, T. Pawson, and J. A. Cooper. 1990. Binding of GAP to activated PDGF receptors. Science 247: 1578-1581.

29. Leevers, S. J., and C. J. Marshall. 1992. Activation of extracellular signal-regulated kinase, ERK2, by p21ras oncoprotein. EMBO J. 11:569-574.

30. Li, B.-Q., D. Kaplan, H.-F. Kung, and T. Kamata. 1992. Nerve growth factor stimulation of the Ras-guanine nucleotide exchange factor and GAP activities. Science 256:1456-1459.

31. Margolis, B., N. Li, A. Koch, M. Mohammadi, D. R. Hurwitz, A. Zilberstein, A. Ullrich, T. Pawson, and J. Schlessinger. 1990. The tyrosine phosphorylated carboxyterminus of the EGF receptor is a binding site for GAP and PLC- $\gamma$. EMBO J. 9:4375-4380.

32. Martegani, E., M. Vanoni, R. Zippel, P. Coccetti, R. Brambilla, C. Ferrari, E. Sturani, and L. Alberghina. 1992. Cloning by functional complementation of a mouse cDNA encoding a homologue of CDC25, a Saccharomyces cerevisiae RAS activator. EMBO J. 11:2151-2157.

33. Martin, G. A., D. Viskochil, G. Bollag, P. C. McCabe, W. J. Crosier, H. Haubruck, L. Conroy, R. Clark, P. O'Connell, R. M. Cawthon, M. A. Innes, and F. McCormick. 1990. The GAPrelated domain of the neurofibromatosis type 1 gene product interacts with ras p21. Cell 63:843-849.

34. McCormick, F. 1989. ras GTPase activating protein: signal transmitter and signal terminator. Cell 56:5-8.

35. Medema, R. H., R. Wubbolts, and J. L. Bos. 1991. Two dominant inhibitory mutants of p21 ${ }^{\text {ras }}$ interfere with insulininduced gene expression. Mol. Cell. Biol. 11:5963-5967.

36. Moran, M. F., P. Polakis, F. McCormick, T. Pawson, and C. Ellis. 1991. Protein-tyrosine kinases regulate the phosphorylation, protein interactions, subcellular distribution, and activity of p21 ras GTPase-activating protein. Mol. Cell. Biol. 11:1804 1812 .

37. Mulcahy, L. S., M. R. Smith, and D. W. Stacey. 1985. Require- ments for ras proto-oncogene function during serum-stimulated growth of NIH 3T3 cells. Nature (London) 313:241-243.

38. Osterop, A. P. R. M., R. H. Medema, G. C. M. van der Zon, J. L. Bos, W. Möller, and J. A. Maassen. Epidermal growth factor receptors generate Ras.GTP more efficiently than insulin receptors, submitted for publication.

39. Pronk, G. J., R. H. Medema, B. M. T. Burgering, R. Clark, F. McCormick, and J. L. Bos. Interaction between the p21ras GTPase activating protein and the insulin receptor. J. Biol. Chem., in press.

40. Satoh, T., M. Endo, M. Nakafuku, T. Akiyama, T. Yamamoto, and Y. Kaziro. 1990. Accumulation of $21^{\text {ras }}$. GTP in response to stimulation with epidermal growth factor and oncogene products with tyrosine kinase activity. Proc. Natl. Acad. Sci. USA 87:7926-7929.

41. Satoh, T., M. Endo, M. Nakafuku, S. Nakamura, and Y. Kaziro. 1990. Platelet-derived growth factor stimulates formation of active p21 ras.GTP complex in Swiss mouse 3T3 cells. Proc. Natl. Acad. Sci. USA 87:5993-5997.

42. Shou, C., C. L. Farnsworth, B. G. Neel, and L. A. Feig. 1992. Molecular cloning of cDNAs encoding a guanine-releasing factor for ras p21. Nature (London) 358:351-354.

43. Stacey, D. W., and H.-F. Kung. 1984. Transformation of NIH 3T3 cells by microinjection of Ha-ras p21 protein. Nature (London) 310:508-511.

44. Stacey, D. W., T. Watson, H.-F. Kung, and T. Curran. 1987. Microinjection of transforming ras protein induces $\mathrm{c}$-fos expression. Mol. Cell. Biol. 7:523-527.

45. Szeberényi, J., H. Cai, and G. M. Cooper. 1990. Effect of a dominant inhibitory Ha-ras mutation on neuronal differentiation of PC12 cells. Mol. Cell. Biol. 10:5324-5332.

46. Tanaka, K., M. Nakafuku, T. Satoh, M. S. Marshall, J. B. Gibbs, K. Matsumoto, Y. Kaziro, and A. Toh-e. 1990. S. cerevisiae genes IRAI and IRA2 encode proteins that may be functionally equivalent to mammalian ras GTPase activating protein. Cell 60:803-807.

47. Thomas, S. M., M. DeMarco, G. D'Arcangelo, S. Halegoua, and J. S. Brugge. 1992. Ras is essential for nerve growth factor- and phorbol ester-induced tyrosine phosphorylation of MAP kinases. Cell 68:1031-1040.

48. Trahey, M., and F. McCormick. 1987. A cytoplasmic protein stimulates normal $\mathrm{N}$-ras p21 GTPase, but does not affect oncogenic mutants. Science 238:542-545.

49. West, M., H. Kung, and T. Kamata. 1990. A novel membrane factor stimulates guanine nucleotide exchange reaction of ras proteins. FEBS Lett. 259:245-248.

50. Wolfman, A., and I. G. Macara. 1990. A cytosolic protein catalyzes the release of GDP from p21 ${ }^{\text {ras }}$. Science 248:67-69.

51. Wood, K. W., C. Sarnecki, T. M. Roberts, and J. Blenis. 1992. ras mediates nerve growth factor receptor modulation of three signal-transducing protein kinases: MAP kinase, Raf-1 and RSK. Cell 68:1041-1050.

52. Xu, G., P. O'Connell, D. Viskochil, R. Cawthon, M. Robertson, M. Culver, D. Dunn, J. Stevens, R. Gesteland, R. White, and R. Weiss. 1990. The neurofibromatosis type 1 gene encodes a protein related to GAP. Cell 62:599-608.

53. Zhang, K., A. G. Papageorge, and D. R. Lowy. 1992. Mechanistic aspects of signaling through ras in NIH 3T3 cells. Science 257:671-674. 